\title{
ОЦЕНКА ВЛИЯНИЯ ЛЕГИРУЮЩИХ ДОБАВОК НА СТРУКТУРУ И МЕХАНИЧЕСКИЕ СВОЙСТВА СЕРЫХ ЧУГУНОВ
}

\author{
Д.А. Габец, А. М. Марков, А. В. Габец, Е. О. Чертовских
}

В современных условиях развития промышленности эфффективным методом повышения эксплуатационной надежности серых чугунов, работающих в сложных режимах ударно-фррикционного износа, является их комплексное легирование. Применение технологии легирование позволяет добиться значительного увеличения механических свойств за счет изменения структуры и характера распределения графита в чугуне. Цель данного исследования заключается в установлении зависимостей влияния легирующих элементов на эксплуатационные свойства серого чугуна, работающего в условиях ударно-фрикционного износа. В статье рассмотрен весь комплекс механических испытаний легированного никелем и молибденом износостойкого чугуна ЧМН-34М в сравнение с базовым чугуном С435, предназначенного для деталей, работающих в условиях ударно-фрикционного износа. Проедены исследования предела прочности при растяжении и сжатии, представлена микроструктура чугуна ЧМН-35 после механических испытаний на излом. Так, предел прочности разработанного износостойкого чугуна составляет от 395 МПа до 450 МПа, а твердость находится в пределах от 276 до 318 НВ. Установлено, что применение технологии легирования способствует формированию структуры с более равномерным распределением графритных включений, что способствует увеличению величины предела прочности сплава при растяжении и сжатии. Проведен анализ результатов фррактографических динамических разрушенных образцов, механизм разрушения серийного и легированного чугуна одинаков, разрушение образцов происходит по хрупкому типу с явным преобладанием межзеренного разрушения, поверхность разрушения в легированном чугуне однороднее.

Ключевые слова: Легирование чугуна, ударно-фрикционный износ, износостойкость, легирование никелем, легирование молибденом, износостойкий чугун, графрит, предел прочности при сжатии.

В современных машинах и механизмах остро стоит вопрос надежности узлов, способных работать в условиях ударнофрикционного износа. Такие изделия должны иметь высокие механические свойства способные обеспечить комплекс свойств, направленных на сопротивление при сжатии и растяжении, а также противостоять износу в сопрягаемых поверхностях. К таким изделиям можно отнести деталей тележки грузового вагона, работающих в условиях интенсивных фррикционных нагрузок. В настоящее время широкая номенклатура деталей тележки может изготавливаться из серого чугуна СЧ35, который достаточно хорошо зарекомендовал себя в сложных режимах эксплуатации. Однако данный чугун имеет в своем составе большое содержание графрита, который в условиях ударно-фррикционного износа может выступать в качестве концентратора зарождения трещин. Одним из перспективных материалов является серый чугун ЧМН-35М легированный никелем и молибденом (патент № 2562554), применение данного материала перспективно при изготовлении таких детаПОЛЗУНОВСКИЙ ВЕСТНИК № 42018 лей как фрикционный клин и колпак скользуна на тележках модели 18-100 или ее аналогов.

Основные требования к получаемому путем легирования износостойкому чугуну относительно низкая себестоимость за счет снижения концентрации дорогих легирующих элементов. При этом механические свойства разрабатываемого материала должны быть достаточно высокими для возможности работы в условиях ударно-фрикционного износа (временное сопротивление при растяжении: не менее 350 МПа, твердость: 250- 300 НВ). Анализ существующих технологий получения износостойких ударопрочных чугунов показал, что имеется зависимость роста механических и прочностных свойств с увеличением процентного содержания никеля и молибдена [1-3].

В качестве базового материала для исследований был выбран серый чугун СЧ35 (ГОСТ 1412-85), легированный никелем и молибденом. Отличительной особенностью данного сплава являются его высокие эксплуатационные и износостойкие свойства. 
Основное применение данного чугуна изготовление литых деталей тележки грузового вагона, работающих в условиях ударнофррикционного износа, таких как фрикционный клин и колпак скользуна.

На основе ранее полученных результатов скорректирована рецептура легирующих элементов, разработаны технические условия (ТУ 0812-001-10036140-2014) на химический состав и механические свойства, приведенные в таблицах 1 и 2, материалу отливки присвоен индекс ЧМН-35М, а также получен патент на изобретение № 2562554 [2].

Таблица 1 - Химический состав чугуна марки ЧМН-35М

\begin{tabular}{|c|c|c|c|c|c|c|c|c|c|}
\hline \multirow{2}{*}{$\begin{array}{c}\text { Марка } \\
\text { Чугуна }\end{array}$} & \multicolumn{8}{|c|}{ Массовая доля элементов, \% Fe-остальное } \\
\cline { 2 - 9 } & $\mathrm{C}$ & $\mathrm{Si}$ & $\mathrm{Mn}$ & $\mathrm{Mo}$ & $\mathrm{Ni}$ & $\mathrm{Cr}$ & $\mathrm{Cu}$ & $P$ & $S$ \\
\cline { 5 - 10 } & & & & & \multicolumn{5}{|c|}{ не более } \\
\hline ЧМН-35M & $2,5 \div 2,9$ & $1,3 \div 1,5$ & $0,7 \div 1,0$ & $0,6 \div 0,9$ & $0,5 \div 0,8$ & $\leq 0,3$ & $\leq 0,3$ & $\leq 0,2$ & $\leq 0,1$ \\
\hline
\end{tabular}

Таблица 2 - Механические свойства чугуна марки чМН-35М

\begin{tabular}{|c|c|c|c|}
\hline \multirow{2}{*}{$\begin{array}{l}\text { Марка } \\
\text { Чугуна }\end{array}$} & \multirow{2}{*}{$\begin{array}{c}\text { Временное сопротивление при } \\
\text { растяжении, МПа, не менее }\end{array}$} & \multicolumn{2}{|c|}{ Твердость по Бринеллю, НВ } \\
\hline & & не менее & не более \\
\hline पMH-35M & 350 & 250 & 300 \\
\hline \multicolumn{4}{|c|}{ 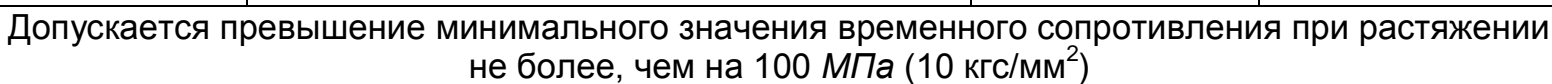 } \\
\hline
\end{tabular}

Для оценки свойств разработанного материала были изготовлены образцы для исследования химического состава, структуры и механических свойств. С целью подтверждения результатов были получены заключения по химическому составу и механическим свойствам от независимых лабораторий. Образцы 1-1, 1-2, 1-3, 2-1, 2-2, 2-3 изготовлены из серого чугуна СЧ35, образцы 3-1, 3-2, 3-3, 4-1, 4-2, 4-3 изготовлены из легированного чугуна
ЧМН-35М, химический состав образцов представлен в таблице 3 [4].

В образцах 1-1, 1-2, 1-3, 2-1, 2-2, 2-3 содержание кремния меньше заданных требований согласно ГОСТ 1412-85. В образцах 41, 4-2, 4-3 превышено содержание углерода согласно ТУ 0812-001-10036140-2014.

Механические свойства при испытании на растяжение полностью удовлетворяют требованиям ТУ на ЧМН-35М (Таблица 4).

Таблица 3 - Химический состав образцов

\begin{tabular}{|c|c|c|c|c|c|c|c|c|c|c|}
\hline \multirow{2}{*}{ № образца } & \multirow{2}{*}{$\begin{array}{l}\text { Марка } \\
\text { чугуна }\end{array}$} & \multicolumn{9}{|c|}{ Массовая доля элементов, \% Fe - остальное } \\
\hline & & C & $\mathrm{Si}$ & $M n$ & Mo & $\mathrm{Ni}$ & $\mathrm{Cr}$ & $\mathrm{Cu}$ & $P$ & $S$ \\
\hline $1-1$ & C435 & 3,21 & 1,05 & 1,0 & 0,002 & 0,071 & 0,2 & 0,135 & 0,02 & 0,032 \\
\hline $1-2$ & C435 & 2,96 & 0,90 & 1,15 & 0,002 & 0,062 & 0,2 & 0,123 & 0,02 & 0,062 \\
\hline $1-3$ & C435 & 2,88 & 0,99 & 1,10 & 0,002 & 0,072 & 0,2 & 0,131 & 0,02 & 0,032 \\
\hline Среднее 1 & C435 & 3,01 & 0,99 & 1,08 & 0,002 & 0,068 & 0,2 & 0,13 & 0,02 & 0,042 \\
\hline $2-1$ & C435 & 3,13 & 1,03 & 1,12 & 0,002 & 0,069 & 0,2 & 0,134 & 0,03 & 0,033 \\
\hline $2-2$ & C435 & 3,11 & 1,03 & 1,03 & 0,002 & 0,068 & 0,2 & 0,134 & 0,03 & 0,030 \\
\hline $2-3$ & C435 & 3,06 & 1,06 & 1,09 & 0,002 & 0,071 & 0,2 & 0,137 & 0,03 & 0,031 \\
\hline Среднее 2 & C435 & 3,10 & 1,04 & 1,08 & 0,002 & 0,069 & 0,2 & 0,135 & 0,03 & 0,031 \\
\hline $3-1$ & $4 \mathrm{MH}-35 \mathrm{M}$ & 2,78 & 1,19 & 0,83 & 0,670 & 0,643 & 0,07 & 0,052 & 0,01 & 0,024 \\
\hline $3-2$ & $4 \mathrm{MH}-35 \mathrm{M}$ & 2,84 & 1,15 & 0,82 & 0,652 & 0,638 & 0,06 & 0,045 & 0,01 & 0,045 \\
\hline $3-3$ & $4 \mathrm{MH}-35 \mathrm{M}$ & 2,76 & 1,13 & 0,81 & 0,644 & 0,635 & 0,05 & 0,050 & 0,01 & 0,022 \\
\hline Среднее 3 & $4 \mathrm{MH}-35 \mathrm{M}$ & 2,79 & 1,16 & 0,82 & 0,655 & 0,639 & 0,06 & 0,049 & 0,01 & 0,030 \\
\hline $4-1$ & $4 \mathrm{MH}-35 \mathrm{M}$ & 3,26 & 1,33 & 0,80 & 0,509 & 0,627 & 0,05 & 0,053 & 0,02 & 0,033 \\
\hline $4-2$ & $4 \mathrm{MH}-35 \mathrm{M}$ & 3,26 & 1,27 & 0,85 & 0,553 & 0,639 & 0,05 & 0,053 & 0,02 & 0,029 \\
\hline $4-3$ & $4 \mathrm{MH}-35 \mathrm{M}$ & 3,19 & 1,15 & 0,71 & 0,487 & 0,631 & 0,05 & 0,049 & 0,02 & 0,024 \\
\hline Среднее 4 & $4 \mathrm{MH}-35 \mathrm{M}$ & 3,23 & 1,25 & 0,79 & 0,519 & 0,633 & 0,05 & 0,052 & 0,02 & 0,029 \\
\hline
\end{tabular}




\section{ОЦЕНКА ВЛИЯНИЯ ЛЕГИРУЮЩИХ ДОБАВОК НА СТРУКТУРУ И МЕХАНИЧЕСКИЕ СВОЙСТВА СЕРЫХ ЧУГУНОВ}

Таблица 4 - Полученные механические свойства чугуна марки ЧМН-35М

\begin{tabular}{|c|c|c|c|}
\hline Марка & $\begin{array}{c}\text { Временное сопротивление при } \\
\text { растяжении, МПа }\end{array}$ & Твердость по Бринеллю, НВ \\
\cline { 3 - 4 } & $380-395$ & 276 & до \\
\hline ЧМН-35M & $325-343$ & 243 & 318 \\
\hline С435 & & & 288 \\
\hline
\end{tabular}

Для испытаний на сжатие применяют универсальные испытательные машины, удовлетворяющие требованиям ГОСТ 28840. Условия, которые должны соблюдаться при испытании на сжатие, те же, что и при испытании на растяжение, но предъявляются более высокие требования к центрированию образца и отсутствию взаимного перекоса нажимных плит, передающих силу на обра- зец.

Образцы для испытаний на сжатие готовятся по ГОСТ 25.503-97. Для исследования прочности серого чугуна СЧЗ5 и легированного никелем и молибденом ЧМН-35М было изготовлено по 6 шт. образцов типа I, диаметром 10 мм, и высотой 20 мм. (рисунок 1). [5-7].

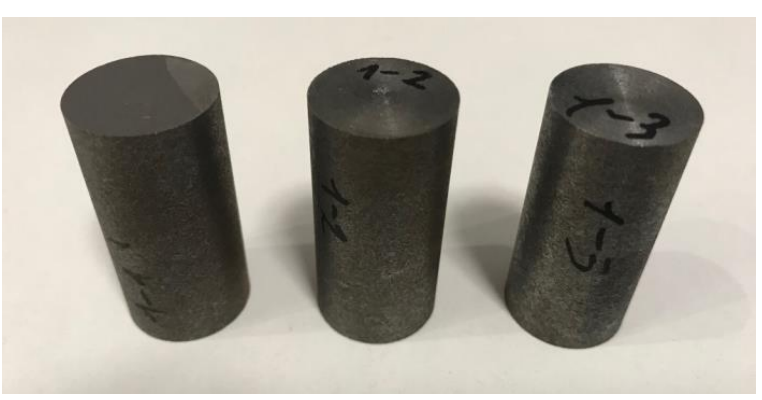

Рисунок 1 - Фото образцов

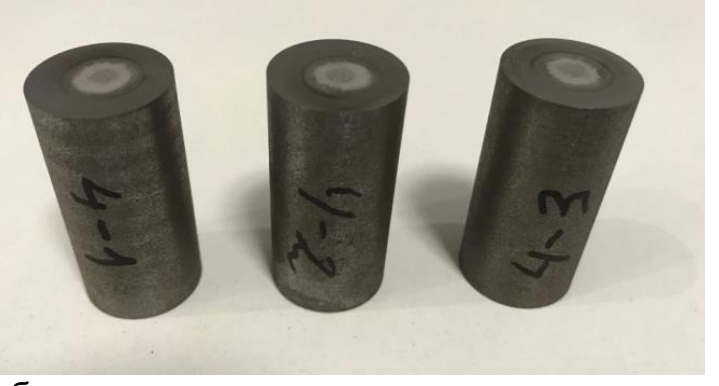

наблюдалось два вида разрушения образцов: полное разрушение образца 1-1 и 2-3 и наклоненное под углом $45^{\circ}$ к оси образца (рисунок 3-4).

Предел прочности при сжатии чугуна С435 в среднем равен 2911 (2564-3226) МПа, предел прочности при сжатии легированного чугуна ЧМН-35 равен 3350 (3196-3559) МПа. Таким образом, предел прочности при сжатии чугуна ЧМН-35М выше, чем стандартного чугуна СЧЗ35 на 13 процентов.

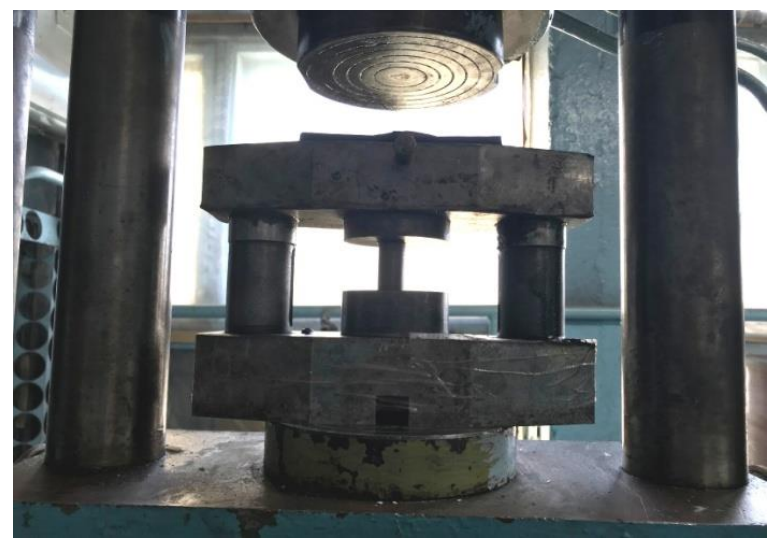

Рисунок 2 - Приспособление 
Таблица 5 - Результаты испытаний серых чугунов

\begin{tabular}{|c|c|c|c|}
\hline № образца & Материал & Предел прочности, кг/см2 & Предел прочности, МПа \\
\hline $1-1$ & СЧ35 & 26150 & 2564 \\
\hline $1-2$ & С435 & 29100 & 2853 \\
\hline $1-3$ & СЧ35 & 31100 & 3049 \\
\hline $2-1$ & С435 & 32900 & 3226 \\
\hline $2-2$ & С435 & 30500 & 2991 \\
\hline $2-3$ & С435 & 28400 & 2785 \\
\hline Среднее & С435 & $29691(26150-32900)$ & 3285 \\
\hline $3-1$ & ЧМН-35M & 33500 & 3226 \\
\hline $3-2$ & ЧМН-35M & 32900 & 3559 \\
\hline $3-3$ & ЧМН-35M & 36300 & 3196 \\
\hline $4-1$ & ЧМН-35M & 32600 & 3353 \\
\hline $4-2$ & ЧМН-35M & 34200 & 3481 \\
\hline $4-3$ & ЧМН-35M & 35500 & $3350(3196-3559)$ \\
\hline Среднее & ЧМН-35M & $34166(32600-35500)$ & $(2564-3226)$ \\
\hline
\end{tabular}
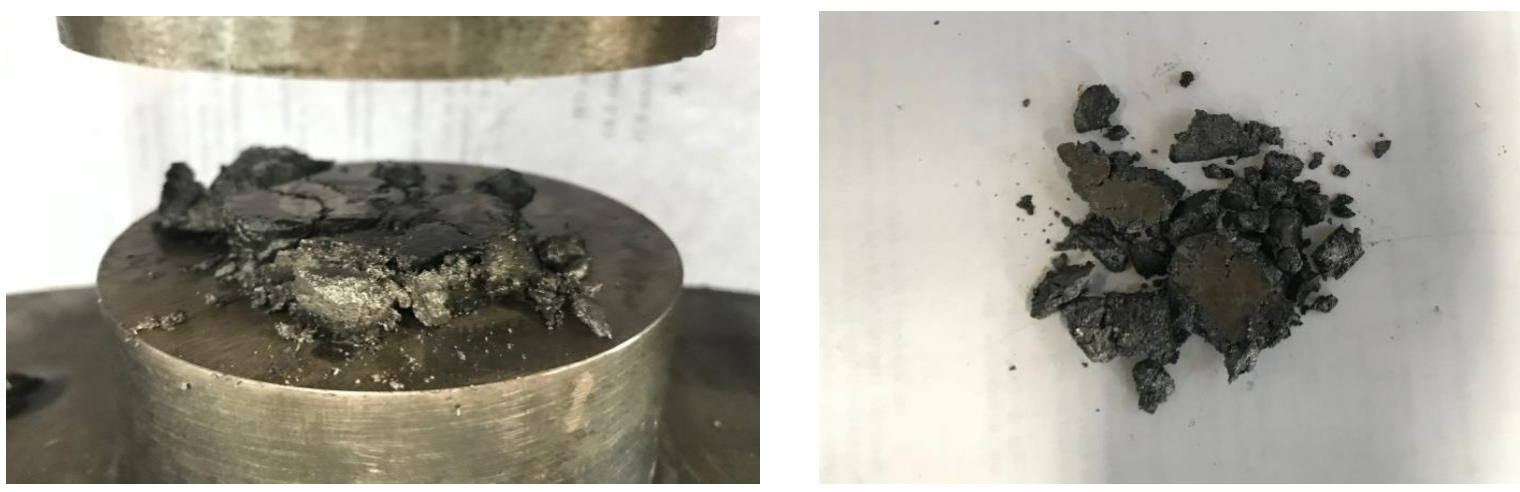

Рисунок 3 - Чугун СЧ35 образец 1-1

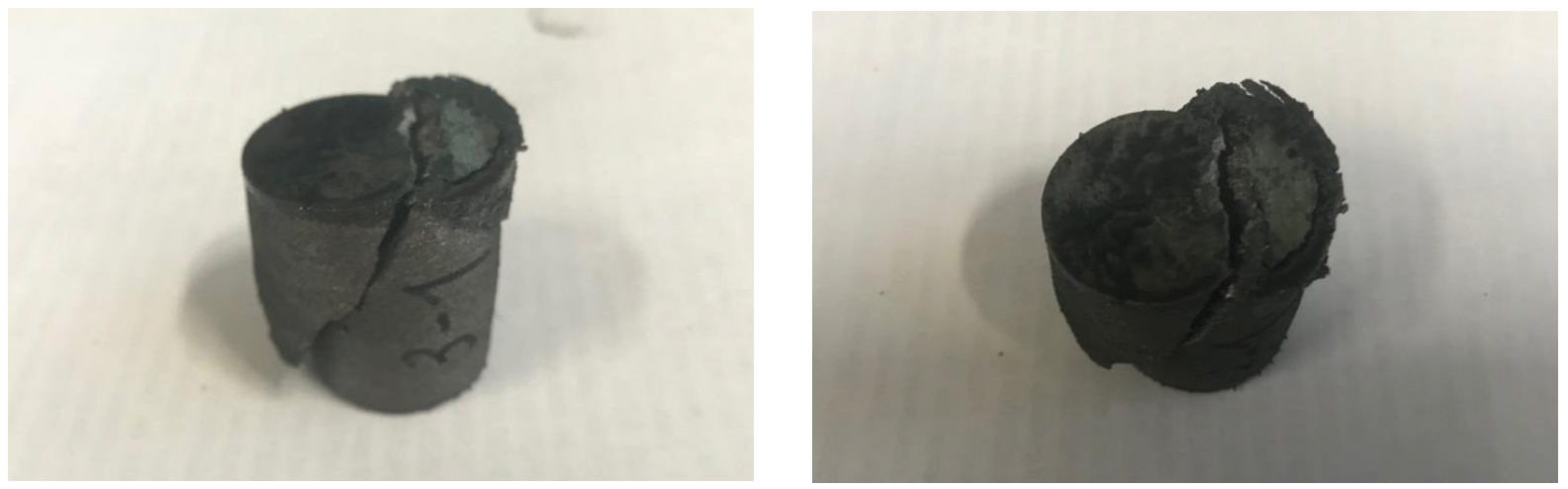

Рисунок 4 - Чугун ЧМН-35М образец 3-1

Результаты исследования образцов на ударный изгиб представлены в таблице 6. Характер разрушения макрохрупкий. Из приведенных данных в таблице видно, что легированный чугун также, как и чугун марки С4 35 , не чувствителен к концентраторам напря- жений. Ударная вязкость образцов практически одинаковая. Это обусловлено наличием графитных включений, которые из-за низкой прочности при разрушении могут рассматриваться как микротрещины [9-10]. 


\section{ОЦЕНКА ВЛИЯНИЯ ЛЕГИРУЮЩИХ ДОБАВОК НА СТРУКТУРУ И МЕХАНИЧЕСКИЕ СВОЙСТВА СЕРЫХ ЧУГУНОВ}

Таблица 6 - Результаты испытаний на ударный изгиб

\begin{tabular}{|c|c|c|c|}
\hline № & $\begin{array}{c}\text { Марка } \\
\text { чугуна }\end{array}$ & Ударная вязкость $K C U$, Дж/см² & Ударная вязкость $K C V$, Дж/см² \\
\hline 1 & ЧМН-35M & $107-112$ & $102-108$ \\
\hline 2 & СЧ35 & $89-95$ & $95-101$ \\
\hline
\end{tabular}

Исследование микроструктуры чугуна проводилось в соответствии с ГОСТ 3443 на микроскопе Niкon Eclipse MA200 методом сравнения с эталонными шкалами. Форму, размер, распределение и площадь графитных включений определяли при увеличении во 100 крат на нетравленом шлифе. Тип металлической основы чугуна и дисперсность перлита определяли после травления в 4\% спиртовом растворе азотной кислоты при увеличении в 500 крат [11-12].

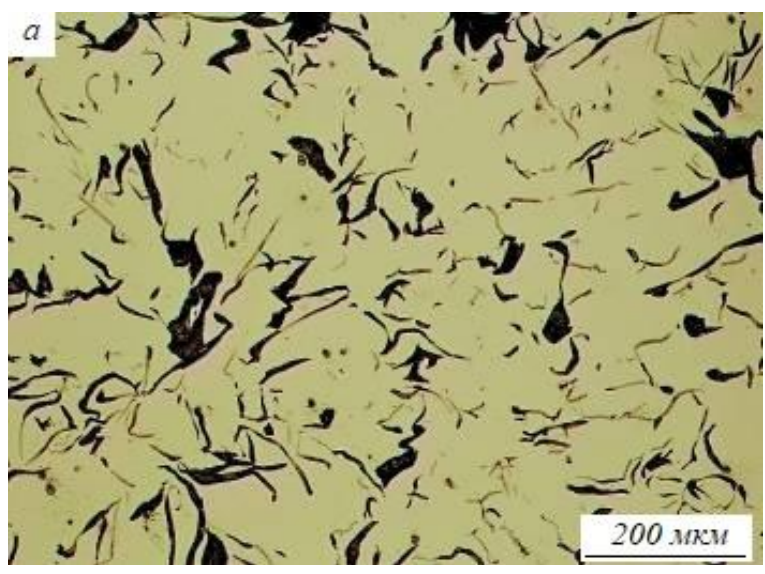

Распределение графитных включений в чугуне СЧ35 смешанное междендритное неравномерное (рисунок 5, а). В чугуне ЧМН35М смешанное (равномерное и участки неравномерного) распределение графита (рисунок 5, б). Металлическая основа чугуна СЧ35 полностью перлитная (рисунок 6, а). Основные отличия легированного чугуна заключаются в структуре металлической основы: наличием перлита и феррита (рисунок 6, б) $[13-14]$.

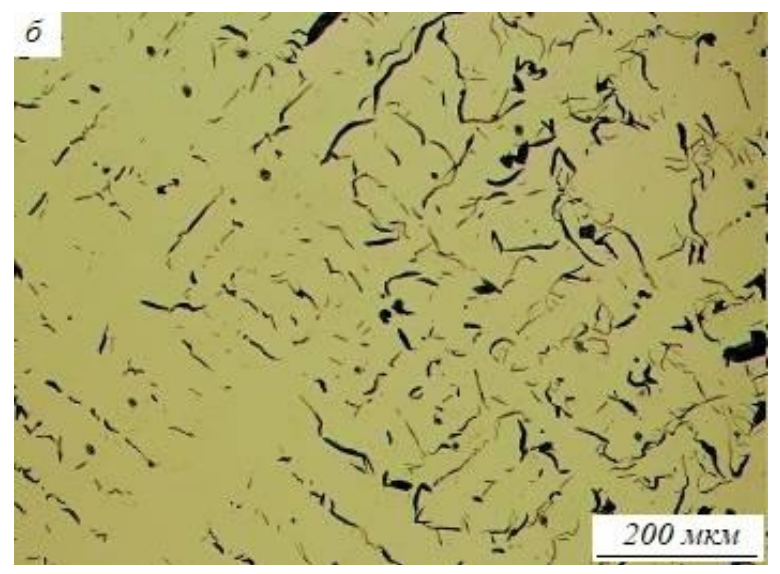

Рисунок 5 - Распределение графита: а) Смешанное и неравномерное в чугуне СЧ35; б) Смешанное в чугуне ЧМН-35M
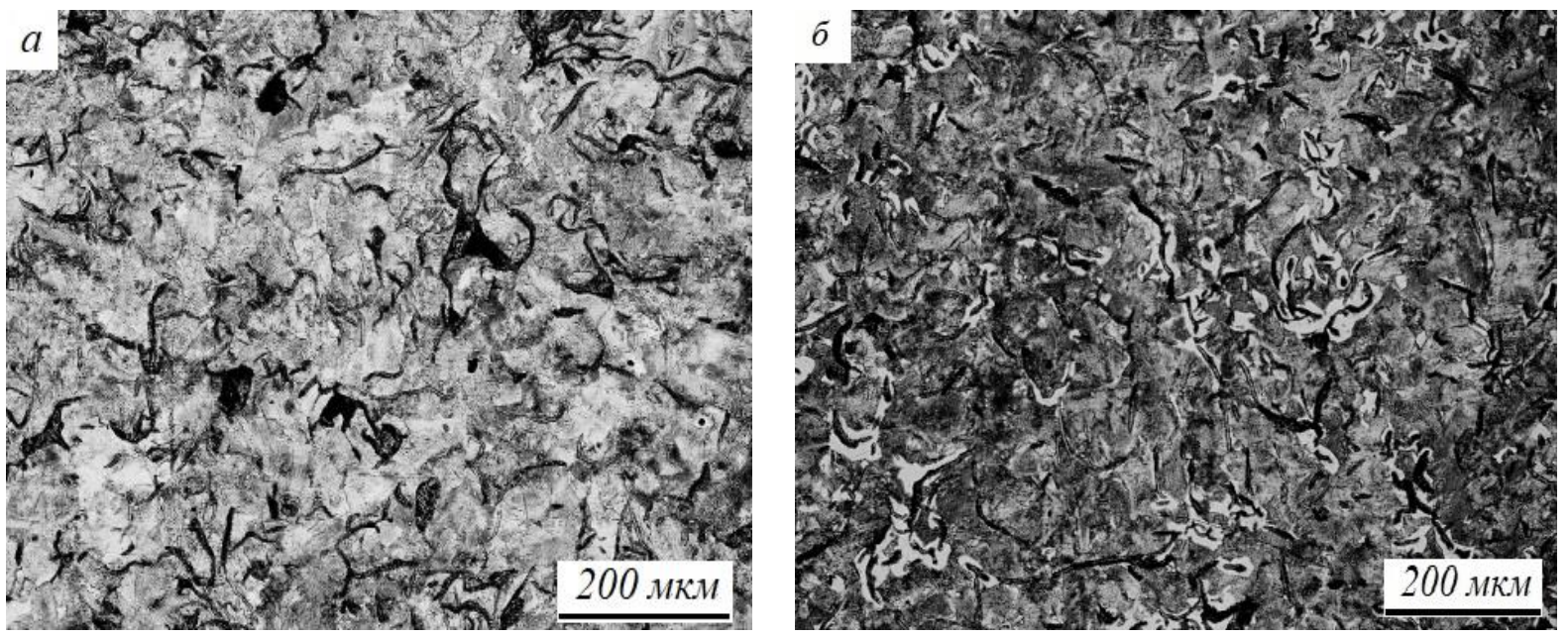

Рисунок 6 - Основа: а) Перлитная в чугуне С435;

б) Перлитно-ферритная в чугуне ЧМН-35М 
Фрактографические исследования образцов проводили на электронном микроскопе Carl Zeiss при увеличениях до 1000 крат. Исследовали поверхность разрушения образцов после испытаний на предел прочности. В области излома имеются фасетки хрупкого скола. У чугуна ЧМН35-М размер фасеток примерно в 1,5 раза мельче чем у СЧ35. Механизм разращения представлен-

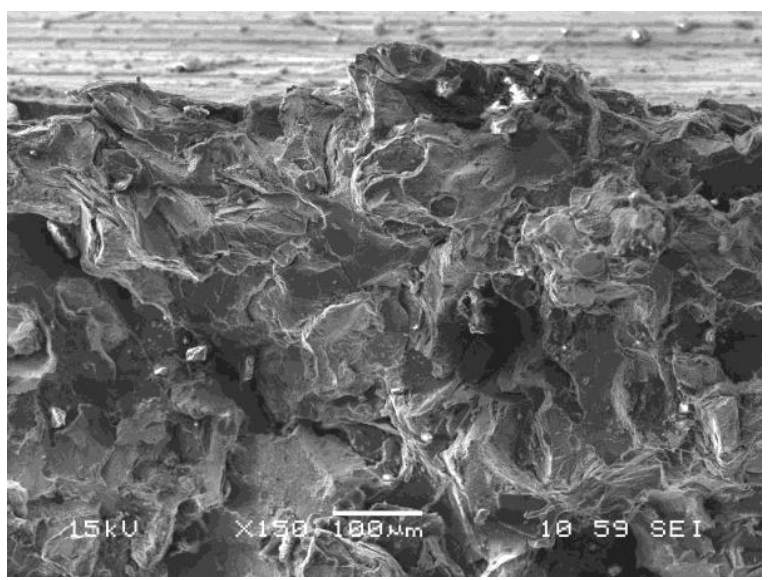

Рисунок 7 - Фрактограмма излома СЧ35 после испытаний

\section{ВЫводы}

1. Предел прочности при сжатии легированного никелем и молибденом чугуна ЧМН35М выше, чем серийного СЧ35 примерно на $13 \%$, это связано, прежде всего, с микроструктурой чугуна, равномерно распределенными графитными включениями, а также более дисперсной металлической основой.

2. Анализ результатов фррактографических исследований динамически разрушенных образцов свидетельствует о том, что механизмы разрушения серого чугуна СЧ35 и разработанного в работе легированного износостойкого чугуна чМН-35М имеют одинаковый характер, как в зонах зарождения, так и в зонах распространения трещин. Разрушение образцов происходит по хрупкому типу с явным преобладанием межзеренного механизма. Поверхности разрушения образцов из ЧМН-35М более однородные, размер фасеток скола составляет от 20 мкм до 60 мкм, что примерно в 1,5 раза мельче, чем у чугуна СЧ35.

3. Предложен состав легированного чугуна чМН-35М повышенной износостойкости. Установлен характер распределения графитовых включений (сочетание равномерного и неравномерного распределения), и металлической основы, состоящей из перли- ных образцов практически одинаков, разрушение проходит с преобладанием межзереного разрушения по хрупкому процессу. Преобладание межзеренного разрушения в области зарождения трещины в изломе образцов модифицированного чугуна чМН35-М и чугуна СЧ35 после испытаний на ударный изгиб (KCU) представлено на рисунке 7-8 [15].

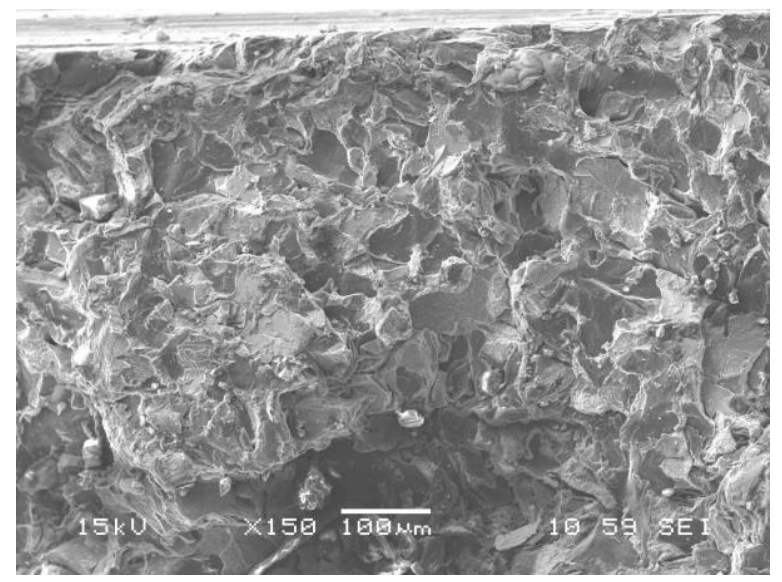

Рисунок 8 - Фрактограмма излома ЧМН-35М после испытаний

та и феррита. Это способствует повышению механических свойств разработанного материала, который может быть использован для изготовления деталей, работающих в условиях ударно-фрикционного износа

\section{СПИСОК ЛИТЕРАТУРЫ}

1. Габец Д.А., Марков А.М., Габец А.В. Исследование влияния химического состава и структуры на механические свойства чугуна ЧМН-35М // Актуальные проблемы в машиностроении. - 2017. - T. 4, № 4. - C. 100-107.

2. Чугун : пат. 2562554 Рос. Федерация. - № 2014118635; заявл. 08.05.2014; опубл. 12.08.2015, Бюл. 25. -5 c.

3. Gabets, A.V., Markov, A.M., Gabets,

D.A., Komarov, P., Chertovskikh, E.O. Investigation of chemical compostition and material structure influence on mechanical properties of special cast iron // METAL 2017 - 26th International Conference on Metallurgy and Materials, Conference Proceedings - ISBN: 9788087294796

4. Корниенко, Э.Н., Бикулов Р.А. Тяжелая лигатура для получения высокопрочного чугуна // Заготовительные производства в машиностроении. - 2009. - № 2. - С. 3-5.

5. Габец А.В., Марков А.М., Габец Д.А., Чертовских Е.О. Управление износостойкостью ответственных узлов и деталей подвижного состава: 


\section{ОЦЕНКА ВЛИЯНИЯ ЛЕГИРУЮЩИХ ДОБАВОК НА СТРУКТУРУ И МЕХАНИЧЕСКИЕ СВОЙСТВА СЕРЫХ ЧУГУНОВ}

монография. - Барнаул: Изд-во АлтГТУ, 2016. 213 с. - ISBN 978-5-7568-1188-9.

6. Коровин В.А., Леушин И.О., Палавин Р.Н., Киров А.С. Влияние модифицирования на структуру и свойства чугуна и стали для прокатных валков // Литейщик России. - 2011. - № 12. - С. 15-17.

7. Gabets, A.V., Gabets, D.A., Markov, A.M., Radchenko, M.V., Leonov, S.L.. Technological Support of Critical Parts for Railway Transport Working Properties // IOP Conference Series: Earth and Environmental Science. DOI: 2-s2/0-85012146259. ISBN: 17551307

8. Vijeesh, V., Prabhu K.N. Review of microstructure evolution in hypereutectic AL-SI alloys and its effect on wear properties // Transactions of the Indian Institute of Metals. - 2014. - Vol. 67, iss 1. Pp. 1-18. - DOI: 10.1007/s12666-013-0327-x.

9. Управление износостойкостью ответственных узлов и деталей подвижного состава: монография / Д. А. Габец [и др.]. - Барнаул : Издво АлтГТУ, 2016. - 213 с.

10. Гольдштейн Я. Е., Мизин В.Г. Модифицирование и микролегирование чугунов и стали. - М.: «Металлургия», 1986.

11.Габец А.В. Специальный чугун для отливки фрикционного клина тележки железнодорожного вагона//Ползуновский вестник. 2013. № 4/2. C.51-52.

12. Комаров, О.С., Розенберг Е.В., Урбанович Н.И. Особенности модифицирования различных типов железоуглеродистых сплавов // Литье и металлургия. - 2015. - № 2 (79). - С. 24-28.

13.Габец, Д.А., Марков А.М., Габец А.В. Специальный модифицированный чугун марки чМН$35 \mathrm{M}$ для тяжело нагруженных деталей тележки грузового вагона // Тяжелое машиностроение. 2016. - № 1-2. - С. 23-26.
14.Габец, А.В., Марков А.М., Габец Д.А. Моделирование эксплуатационных свойств деталей, изготовленных из специального чугуна ЧМН-35М // Ползуновский вестник. - 2016. - № 2. - С. 36-44.

15. Борщ Б.В., Габец А.В., Сухов А.В., Филиппов Г.А. Повышение износостойкости фрикционных деталей из серого чугуна // Сталь. - 2014. № 1. - С. 66-68.

Габец Денис Александрович, Инженер НИС, ФГБОУ ВО «АлтайскИй государственный технический университет им. И. И Ползунова», 656038, г. Барнаул, пр. Ленина 46, e-mail: gabets22@mail.ru.

Марков Андрей Михайлович, доктор технических наук, профессор, Профессор кафредры «Технология машиностроения» ФГБОУ ВО «АлтайскИй государственный технический университет им. И. И Ползунова», 656038, г. Барнаул, пр. Ленина 46, email: andmarkov@inbox.ru.

Габец Александр Валерьевич, кандидат технических наук, директор по развитию $О О О$ «СИбТрансМаш», 656012, г. Барнаул, ул. Папанинцев, д. 97. e-mail: gabeca@mail.ru.

Чертовских Евгений Олегович, кандидаm технических наук, инженер ОГМЕТ ООО «АСЛЗ», 6560, 656037, пр. Калинина 116/52, e-mail: chertovskih13@gmail.com. 